\title{
Mindfulness as a Potential Tool for Developing the Personality of the Social Worker ${ }^{1}$ Michal Kaczor
}

\section{Introduction}

Developing the personality of a social worker (respectively, the continual care of his or her overall health) is crucial in the performance of his or her profession. Unlike other professions (for example, craftsmanship), he or she comes into contact almost permanently with living beings, i.e., clients. A healthy or unhealthy mental or physical state is then reflected in mutual interactions. Šuráňová mentions that mental health is essential in the performance of a social worker's profession. Thanks to this, he or she is able to work efficiently on a long-term basis. However, if the tools for continuous work with himself or herself are missing, external pressures may slowly 'crush' him or her. This then leads to the progressive extinction of mental and physical energy. ${ }^{2}$ There is (therefore) a need to have tools for the long-term development of personality. One of them can be mindfulness. This helps practitioners to silence their busy minds, to become more aware of the present moment, and 'to be less imprisoned' in thoughts of the past or the future. This is an effective tool for dealing not only with anxiety and depression. In the broadest sense, mindfulness is perceived as a tool for dealing with stress - a common cause of mental and physical illness in the 21 st century. ${ }^{3}$

\section{What is mindfulness?}

Mindfulness comes from two key sources. First, there is a Buddhist direction giving the basis for a specific psychology that involves the study of meditation and its effect on the functioning of the human brain. Second, there is social learning and other approaches in cognitive behavioural thera$p y$, based on emphasising the importance of concentrating attention on defined behaviour. ${ }^{4}$ The very notion of mindfulness comes from the traditional Buddhist psychology preserved in the ethical and psychological system of abhidhamma. Its development is associated with the practice of the Buddhist meditation of mindfulness and insight - satipatthana-vipassana. Man observes his or her own mental and physical processes to recognise their temporary, unsatisfactory and impersonal nature..$^{5}$ An important personality in the subject of mindfulness was Buddha. He devoted

The article is the outcome of GAJU Specific Research Project No. 157/2016 / H.

2 Cf. Veronika ŠURÁŇOVÁ, Využití všímavosti (mindfulness) v duševní hygieně pomáhajících profesí, in: SAPERE AUDE 2012: Vzdělávání a dnešní společnosti, Hradec Králové: Magnanimitas, 2012, p. 573.

3 Cf. Kate PICKERT, The Mindful Revolution: The Science of Finding Focus in a Stressed-Out, Multitasking Culture, TIME 3/2014, p. 42. Cf. Malcolm PAYNE, Modern Social Work Theory, Oxford: Oxford University Press, 2016, p. 167.

Cf. Jan BENDA, Meditace, všímavost a nové směry v KBT, Konfrontace - časopis pro psychoterapii 3/2006, pp. $132-135$. 
himself to the development and keeping of mindfulness. In his teaching, he did not neglect the exceptional contribution of these practices. ${ }^{6}$ Mindfulness has risen from ancient spiritual practices. In the life of many individuals, spirituality (or religious practices) are the key part of their existence. It can also be an important source of power, and (at the same time) fulfil the function of tools to handle difficult moments of life. ${ }^{7}$ The sources of mindfulness (as a concept) are therefore the spiritual movements of the East and the West. In addition, meditation has been an important practice in major world religions such as Hinduism, Confucianism, Taoism, Buddhism, Judaism, Islam and Christianity. ${ }^{8}$

At present, mindfulness is a frequently used term. The rapid pace of postmodern society undoubtedly contributes to its usage. A number of well-known authors deal with current society in their written work - Bauman, Beck, Keller, Lipovetsky and others. ${ }^{9}$ The demand for effective tools (which have the potential to activate the overwhelmed, disturbed mind and maintain health in optimum condition) is therefore legitimately increasing. Social work also becomes a subject of interest as one of the helping professions characterised by a great burden..$^{10}$ Hick and Bien pointed out that practitioners from various fields (based on a relationship with a client) have an unusual interest in mindfulness. This is also because (among other factors) it has a positive influence on the intervention - both on the client's and the professional's side. He or she can through mindfulness (for example) cultivate empathy and love by developing awareness of being in the presence of him or her, listening skills, enhancing the ability to withstand work and home stress, or reducing the likelihood of developing burnout syndrome. ${ }^{11}$ Social workers are an 'engine' or an indispensable tool for an effective helping process. ${ }^{12}$ It is therefore necessary to pay attention to such means as to develop their personality and to keep mental and physical health in balance. One of them is the mindfulness that is dealt with in this article. It has significant contact points with social work. For both, an individual, lived experience (in the context of one's unique life) has an important and honoured value. In addition, mindfulness (as well as social work) includes self-care (including self-acceptance) as a fundamental value in its approach. Similarly, a non-evaluative approach is a characteristic sign for both mindfulness and social work. ${ }^{13}$ Caring for oneself is an important aspect in the practice of a social worker. He or she can use mindfulness in various ways - to reduce stress, to make oneself calm, to increase awareness, etc. ${ }^{14}$ In addition, mindfulness is a quality that can help a social worker to approach all situations related to his or her practice with clarity, concentration and compassion. ${ }^{15}$

Mindfulness is usually defined as 'the awareness of individual moments' or 'focusing one's attention on the present moment, without assessment and evaluation' and supports attention to every

6 Cf. Michael CHASKALSON, Mindfulness za 8 týdnư, Praha: BizBooks, 2017, p. 18.

7 Cf. Marsha M. LINEHAN, DBT Skills Training Manual, New York: Guilford Press, 2015, p. 156.

8 Cf. Lloyd RIDGEON, Major Religions of the World, New York: Taylor \& Francis, 2003.

9 Cf. Zygmunt BAUMAN, Úvahy o postmoderní době, Praha: SLON, 2006; Ulrich BECK, Riziková společnost: Na cestě kjiné moderně, Praha: SLON, 2011; Jan KELLER, Posvícení bezdomovců: Úvod do sociologie domova, Praha: SLON, 2013; Gilles LIPOVETSKY, Hypermoderni doba: Od požitku k úzkosti, Praha: Prostor, 2013.

10 Cf. Jitka GÉRINGOVÁ, Pomáhající profese: Tvořivé zacházení s odvrácenou stranou, Praha: Triton, 2011, p. 36; Jiří JANKOVSKÝ, Etika pro pomáhajicí profese, Praha: Triton, 2003, pp. 157-165; Oldřich MATOUŠEK, Metody a řízení sociální práce, Praha: Portál, 2008, pp. 51-60; Zdeněk MLČÁK, Potenciální zdroje stresu v sociální práci a jejich zvládání, Sociální práce / Sociálna práca 3/2005, pp. 124-137.

11 Cf. Steven F. HICK - Thomas BIEN, Mindfulness and the Therapeutic Relationship, New York: The Guilford Press, 2010 , p. 4.

12 Cf. Andrej MÁTEL - Milan SCHAVEL - Pavel MÜHLPACHR - Tibor ROMAN, Aplikovaná etika v sociální práci, Brno: Institut mezioborových studií, 2010, pp. 93-94; Karel KOPǨIVA, Lidský vztah jako součást profese, Praha: Portál, 2006, p. 94.

13 Cf. Francis J. TURNER, Social Work Treatment: Interlocking Theoretical Approaches, Oxford: Oxford University Press, 2017, pp. 335-336.

14 Cf. Aneesha KELLY - Ifeoma OKOLO, Mindfulness Meditation as a Self-Care Practice in Social Work, in: Master of Social Work Clinical Research Papers, Minnesota: School of Social Work, 2016, p. 2.

15 Cf. Edward R. CANDA - Leola D. FURMAN, Spiritual Diversity in Social Work Practice: The Heart of Helping, Oxford: Oxford University Press, 2010, p. 362. 
movement, breath, feeling and thought. ${ }^{16}$ One of the mindfulness pioneers, Dr Jon Kabat-Zinn, states that:

Mindfulness is consciousness, shaped by attention in a continuous and specific way: deliberately, at the present moment, objectively (uncritically). It is one way of meditation if we understand meditation as: 1 . Systematic directing of our attention and energy, thanks to it then 2. influencing and transforming our experiences, 3 . throughout the recognition of the whole spectrum of humanity, and 4 . our relationships with other people and the world. ${ }^{17}$

It also mentions that mindfulness is a powerful tool for self-understanding of the individual and the key to a comprehensive improvement of his or her health..$^{18}$ Hasson concretises what is at the core of this approach: 'Mindfulness can help a person to overcome the throbbing stream of thoughts that are constantly chasing him or her. ${ }^{19}$ She adds that the technique of mindfulness can be better represented in analogy to the commented sports match on television. If the viewer turns off the sound (i.e., the game's commentary), the game can be perceived much more directly. Similar$l y$, it is with a subjective commentary on the objective experiences. ${ }^{20}$ Sinclair and Seydel compare mindfulness to the opposite of life as 'being in autopilot mode'. It allows you to move closer to inner peace and stability while strengthening and cultivating them. Mindfulness ultimately helps to reduce stress, to relax, to develop resistance to stress, to improve the efficiency and effectiveness of work, to use natural resources of physical and mental energy, or to be open to creativity. ${ }^{21}$

Mindfulness therefore appears to be a very effective tool, not only when dealing with the workload generated by helping professions. It is also applicable in the complex development of the personality of social workers. The following chapter interprets the results of some scientific researches.

\section{What is said about the effectiveness of mindfulness in some scientific research?}

There has been a countless number of research projects in the area of mindfulness. Due to the limited space, only some of them will be listed which can serve as a reference group to demonstrate the effectiveness of mindfulness not only in social work but also in many other professions (with the core based on working with people). Research shows that through mindfulness one can gradually achieve the desired results, such as acceptance, the ability to let things be as they are, a non-judgemental attitude or self-confidence. Mindfulness facilitates changes in the inner and outer world not only for social workers but also for clients. ${ }^{22}$

Kelly and Okolo in their research paid attention to social workers and their care for themselves. Authors wondered if interventions in the form of a 6-week training of mindfulness would have

16 Cf. Robyn LYNN - Jo MENSINGA, Social Workers' Narratives of Integrating Mindfulness into Practice, Journal of Social Work Practice 3/2015, pp. 255-256.

17 Jon KABAT-ZINN, Mindfulness for Beginners: Reclaiming the Present Moment - and Your Life, Colorado: Sounds True, 2012 , p. 1.

18 Cf. Jon KABAT-ZINN, Život samá pohroma: Jak čelit stresu, nemoci a bolesti pomocí moudrosti těla a mysli, Brno: Jan Melvil Publishing, 2016.

19 Gill HASSON, Technika mindfulness: Jak se vyvarovat duševni prokrastinace prostřednictvím všímavosti a bdělé pozornosti, Praha: Grada, 2015, p. 28.

20 Cf. ibid.

21 Cf. Michael SINCLAIR - Josie SEYDEL, Všimavost: Cesta pro zklidnění mysli pro ty, co nestíhají, Praha: Grada, 2015, p. 26.

22 Cf. Liora BIRNBAUM - Aiton BIRNBAUM, Mindful Social Work: From Theory to Practice, Journal of Religion \& Spirituality in Social Work: Social Thought 1-2/2008, pp. 87-104. 
a positive impact on their lives. The results have shown that this intervention in the care of social workers has increased the level of self-esteem and satisfaction in the field of compassion. On the contrary, the likelihood of burnout syndrome or secondary traumatic stress has decreased. The research has thus confirmed that the inclusion of mindfulness-based practices in the everyday life of social workers can bring great benefits. ${ }^{23}$

Two studies were conducted in further research. The first one was observing whether a shortterm intervention through mindfulness among professionals working with people (nurses) was more effective than an intervention through traditional relaxation. The results showed that both are effective, especially in the area of relaxation and life satisfaction. In addition, respondents who have practised mindfulness have increased resistance to emotional exhaustion. In the second study, respondents (pedagogical practitioners), who participated in Mindfulness-Based Wellness Education (MBWE), showed significantly higher values in areas of mindfulness, satisfaction with life, or self-confidence in teaching. ${ }^{24}$

$\mathrm{McGarrigle}$ and Walsh in their research tracked the effectiveness of an 8-week contemplative training session. They were interested in the following areas: raising selfcare, level of mindfulness, and coping strategies for 12 respondents who work with people in their jobs. It turned out that during the intervention, mindfulness increased significantly, and the level of stress was greatly reduced. It was documented that (through the practices of mindfulness) any social worker can increase not only in selfcare but also in the relationship with the clients (or more so service, as such). ${ }^{25}$

A remarkable piece of research was carried out by Birnbaum. It was dedicated to students of social work. She warned of the familiar fact that they regularly experience emotional stress and (at the same time) are forced to fulfil expectations - both academically and professionally. Due to these facts, they can often feel physically and emotionally overloaded. They need adequate time and space to process these diverse experiences fully and efficiently. The group participating in the research met with a mindfulness technique within eight weeks. The aim was to increase self-confidence and emotional support when dealing with academic stressors. According to the research findings, students were able to gain new knowledge about themselves, also experience autonomy in learning, were able to re-restore and regulate their psychological state, and gain insight into their professional self-concept. ${ }^{26}$ Students of social work, specifically in the last year of study, were part of the research conducted by Howie, Innes and Harvey. Authors in the research used mindfulness training based on Dr Jon Kabat-Zinn's well-known MBSR program (Mindfulness-Based Stress Reduction). Students' feedback showed a number of personal and professional benefits. These, among others, included support for psychological resilience and the ability to be aware of things. ${ }^{27}$ Napoli and Bonifas were observing the graduates of social work who attended a 16 -week course focusing on self-care and career development through formal and informal mindfulness strategies. Four areas were tested: conscious behaviour, observation, acceptance without judge-

23 Cf. Aneesha KELLY - Ifeoma OKOLO, Mindfulness Meditation as a Self-Care Practice in Social Work, in: Master of Social Work Clinical Research Papers, Minnesota: School of Social Work, 2016.

24 Cf. Patricia A. POULIN - Corey S. MACKENZIE - Geoffrey SOLOWAY - Eric KARAYOLAS, Mindfulness Training as an EvidenceBased Approach to Reducing Stress and Promoting Well-Being among Human Services Professionals, International Journal of Health Promotion and Education 2/2008, pp. 72-80.

25 Cf. Tessa McGARRIGLE - Christine A. WALSH, Mindfulness, Self-Care, and Wellness in Social Work: Effects of Contemplative Training, Journal of Religion \& Spirituality in Social Work: Social Thought 3/2011, pp. 212-233.

26 Cf. Liora BIRNBAUM, The Use of Mindfulness Training to Create an 'Accompanying Place' for Social Work Students, Social Work Education: The International Journal 8/2008, pp. 837-852.

27 Cf. Jayne HOWIE - Debbie INNES - Paul HARVEY, Promoting Conscious Competence by Introducing Mindfulness to Social Work Students, The Journal of Practice Teaching and Learning 1/2016, pp. 88-104. 
ment, description. The results showed that students significantly increased the use of mindfulness in the first three areas. ${ }^{28}$

There has also been evidence of a link between mindfulness training and emotional intelligence. Li-Chuan Chu's research showed the positive benefits of meditation in connection with emotional intelligence (EI), perception of stress and negative mental health. In number, 351 adults, working full-time, with different experiences in meditation, were observed. It was confirmed that respondents with greater meditation experience showed a higher level of emotional intelligence (EI) and less perceived stress and negative mental health. Thus, meditation training, according to this study, improves overall human condition..$^{29}$

Research by Shier and Graham analysed the subjective well-being of social workers in relation to their state of mindfulness. From an initial survey of 700 social workers, 13 were selected who showed the highest scores of subjective well-being. They confirmed that mindfulness influenced their overall subjective well-being. They also indicated that there were certain aspects of their life that they needed to be mindful. These include: reflecting and developing personal identity, thinking about control issues and openness, reflecting key moments in life and maintaining some balance between personal and working life. ${ }^{30}$

Doxtdator summarises his research by saying that mindfulness can provide social workers with the means to return to the place of authenticity and meaning, to return the sense of the meaning of their job that has often brought them to the profession. ${ }^{31}$

Surveys focusing on mindfulness are increasing and it seems that research of mindfulness and its multifaceted positive impact on the personality of a social worker is of great interest in various parts of the world. This is mainly foreign research. In the Czech Republic, however, there is a lot of space for social work, as will be outlined in the next chapter. It should also be noted that the results of foreign research can be quite optimistic for the reader. This is, on the one hand, a positive signal. It supports the statement that mindfulness can be one of those methods contributing to the psychological calmness of some individuals. On the other hand, however, the results of foreign research cannot be accepted uncritically. There is a need to go deeper into their methodological limits and other factors that potentially distort outputs. This is, unfortunately, beyond the capacity of this article. However, at least some critical studies related to the practice of mindfulness are presented in the chapter titled The Drawback of Mindfulness: Possible Risks of Mindfulness.

\section{The Current State of Social Work as a Space for Mindfulness}

Contemporary social work takes place within the framework of significant social changes brought by postmodern society. This can be characterised as a historically significant moment when the institutional barriers (which until then had functioned as reins limiting the individual and making his or her own emancipation difficult) were diminished. As a result, there is more space to build self-realisation. At the same time, systems (which initially had served the socialisation of individuals and had given their lives a 'firm framework') were weakened. ${ }^{32}$ This refers to a signifi-

28 Cf. Maria NAPOLI - Robin BONIFAS, From Theory Toward Emphatic Self-Care: Creating a Mindful Classroom for Social Work Students, Social Work Education: The International Journal 6/2011, pp. 635-649.

29 Cf. Li-Chuan CHU, The Benefits of Meditation vis-à-vis Emotional Intelligence, Perceived Stress and Negative Mental Health, Stress \& Health 2/2010, pp. 169-180.

30 Cf. Micheal L. SHIER - John R. GRAHAM, Mindfulness, Subjective Well-Being, and Social Work: Insight into their Interconnection from Social Work Practitioners, Social Work Education: The International Journal 1/2011, pp. 29-44.

31 Cf. Mary L. DOXTDATOR, Mindfulness: Helping Social Workers Bring Themselves Home, Ontario: McMaster University, 2012.

32 Cf. Gilles LIPOVETSKY, Hypermoderní doba: Od požitku k úzkosti, Praha: Prostor, 2013, pp. 18-22. 
cant social disunity, respectively the diversity and variability of social problems faced by a social worker. He or she must be able to react flexibly to this changing society (i.e., to new social transformations and context). ${ }^{33}$ This itself is associated with numerous stress factors that must be absorbed (while carrying out the profession) in order to protect the social worker's health, whether mental or physical.

With regard to the overall burden, the relationship between the social worker and the client is crucial. It is the core of the helping process. Social workers are required to support people (or clients) in different life situations and circumstances. This can contribute to high levels of stress and even to burnout syndrome. ${ }^{34}$ As Paulík mentions, a part of this relationship is not only professional help (when solving problematic situations beyond the client's current adaptive capacity) but also an empathetic approach to clients, an effort to understand and deal with various disruptive influences (such as the accumulation of work tasks, conflict of professional roles, bureaucracy, risk of attack by the client, lack of work evaluation, shortcomings in legislation, etc.). ${ }^{35}$ The common denominator of a helping process (or mutual connector of those social workers) is that they come into contact with others. It is just their mindfulness which can give them some effective tools to minimise the burden associated with their profession. In addition, it is the way for better processing of their own experience and for deeper understanding of other people's problems (including enhancing their personal competencies for work - sincerity and empathy). ${ }^{36}$ Mindfulness can be a creative and usable tool for all those who want to use it in their favour - in a way that is effective for them. It can significantly reduce the level of stress and estimate balance more effectively among the demands that one faces in life. Social workers can use mindfulness, for example, to prevent burnout syndrome and to raise their awareness. ${ }^{37}$ Mindfulness includes orientation to the present moment. This makes it easier to record what is happening at the moment, and to prevent (more effectively) the usual tendency to worry about the past, or to look at what the future will bring. Orientation to the present moment can bring inner peace and facilitate a more attentive approach towards working with others. This is very important in social work. Mindfulness also includes procedures to strengthen self-confidence and self-acceptance. Accepting what is happening in the present moment can significantly change the relationship to negative emotions and states of mind. All of this allows social workers to take care of themselves. This is an essential prerequisite for taking care of others effectively. ${ }^{38}$ It has been shown that the focus on the present moment is beneficial at the level of the individual, as well as in groups or communities, especially in areas of increased attention, increased self-awareness, empathy and compassion, inner peace, greater insight and transformative ways of how to live and be. ${ }^{39}$

There are many benefits when applying mindfulness, for example: increase in work performance (respectively work efficiency), improved communication and problem solving, increased concentration, increased ability to manage conflicts, achieving balance and resilience at the workplace

33 Cf. Jiřina ŠIKLOVÁ, Medailón, Sociální práce / Sociálna práca 2/2010, p. 2; Karel PAULÍK, K otázce zvládání pracovních nároků v sociální práci, Kontakt - časopis pro ošetřovatelství a sociální vědy ve zdraví a nemoci 2/2006, pp. 292-293.

34 Cf. McGARRIGLE - WALSH, Mindfulness..., p. 212.

35 Cf. Karel PAULÍK, K otázce..., p. 293; cf. Jana STEJSKALOVÁ, Krize sociální práce aneb máme to ještě ve svých rukou?, Sociální práce / Sociálna práca 3/2014, p. 11.

36 Cf. Karel HÁJEK, Satiterapie vybaví sociálního pracovníka nástroji, kterými může minimalizovat zátěž z pomáhající profese, Sociální práce / Sociálna práca 4/2008, p. 40.

37 Cf. Allison L. LEONARD, Breathe In, Breathe Out: Utilizing Mindfulness in Social Work Practicum, in: Undergraduate Honors Theses, Utah: Utah State University, 2012, p. 2.

38 Cf. Steven F. HICK, Mindfulness and Social Work: Paying Attention to Ourselves, Our Clients, and Society, in: Mindfulness and Social Work, Chicago: Lyceum Books, 2009, p. 24.

39 Cf. LYNN - MENSINGA, Social Workers' Narratives..., p. 256. 
and at home, improving comprehensibility and empowering creative thinking, supporting mental and physical wellbeing, reducing stress levels, preventing burnout syndrome and emotional exhaustion, reduction of automatic and customary responses (i.e., the ability to make decisions more consciously), reducing chronic pain, improving energy levels, increasing control of longterm anxiety disorders, improving professional practice and working relationships. ${ }^{40}$ In addition, a social worker practising mindfulness may be more aware of the things that are dysfunctional in his or her workplace, and also can take a critical stance on them. ${ }^{41}$

In connection with the benefits mentioned (respectively the positive consequences), one should be aware of the fact that the practice of mindfulness also requires some investment. In the case of the courses (MBSR, MBCT), as outlined in the next chapter, it is essential to attend regular meetings during the eight-week course. There is a structured homework plan which has to be fulfilled every day. Participants have to find some time for it regularly. Some continuing practice is also expected after the end of this course. As Kabat-Zinn mentions, the basic pillars of mindfulness are seven attitudinal factors - non-judgment, patience, a beginner's mind, confidence, not striving, acceptance, an ability to let go. These factors be adequately cultivated by regular practice only. ${ }^{42}$ The abovementioned shows that mindfulness can be a comprehensive tool for social workers to develop their personality, if the social worker is willing to invest the necessary effort into the development of mindfulness practice. Later, there are specific ways for social workers to develop, improve, and maintain mindfulness.

\section{Opportunities through which Social Workers Can Develop, Improve and Maintain Mindfulness}

First of all, it is important to realise that there are different approaches towards the training of mindfulness. In this chapter, there are two main ones and a social worker can choose the one closest to him or her and use it to develop his or her personality (not only in terms of building psychological resilience or concentration, he or she can also use many benefits that have been outlined in the previous chapters). Also, in his publication Modern Social Work Theory, Payne lists (along with several others) these two forms of mindfulness training. ${ }^{43}$ Their advantage is that they are applicable in both ways. During the development of the social worker's personality and also when handling the various troubles of his or her clients (such as working with depression, low self-esteem, overeating, etc.). However, a social worker does not necessarily have to use a comprehensive, sophisticated and proven MBSR, MBCT (listed below), or other 'varieties' of mindfulness training. It can be his or her own way. There are many professional publications, such as the work of Jon Kabat-Zinn Full Catastrophe Living: Using the Wisdom of Your Body and Mind to Face Stress, Pain, and Illness ${ }^{44}$, which are designed as a specific manual (or alternative) of mindfulness training for self-taught. These can be used mainly by individuals who do not want to enter paid and professionally trained courses.

40 Cf. (C) SSSC News, Bringing Mindfulness to Social Work (on-line), available at: http://ssscnews.uk.com/2014/11/27/bringingmindfulness-workplace-social-work, cited 1st July 2017; cf. Louise GRANT - Gail KINMAN, Developing Resilience for Social Work Practice, UK: Palgrave, 2014.

41 Cf. Jim ROGERS - Lucy BRIGHT - Helen DAVIES, Social Work with Adults, UK: Sage Publications, 2015.

42 Cf. Jon KABAT-ZINN, Full Catastrophe Living: Using the Wisdom of Your Body and Mind to Face Stress, Pain and Illness, New York: Batam Books, 2013, p. 21.

43 Cf. Malcolm PAYNE, Modern Social Work..., p. 167.

44 Cf. Jon KABAT-ZINN, Život samá pohroma: Jak čelit stresu, nemoci a bolesti pomocí moudrosti těla a mysli, Brno: Jan Melvil Publishing, 2016. 
- MBSR (Mindfulness-Based Stress Reduction) - this was established in 70 's of the $20^{\text {th }}$ century in the United States of America. It was mainly used in a clinical environment with individuals diagnosed with a wide range of health problems - from being over-stressed or having addictions, to chronic pain. MBSR uses research of a proven eight-week syllabus developed by Jon KabatZinn. ${ }^{45}$ Trainees are trained in self-observation and stress management using formal stress-reducing techniques (such as yoga) and are guided to become more aware of stressors in day-to-day activities. The group discussion within the training is then used to support individual learning. ${ }^{46}$

- MBCT (Mindfulness-Based Cognitive Therapy) - MBSR and MBCT share about 80 percent of content - they are closely related. The main difference between them is that MBSR focuses on mental illness (such as stress, anxiety, fear) in general, and MBCT focuses more on how one thinks. MBCT training was created in the UK in 1990 by Zindal Segal, Mark Williams and John Teasdale. These MBCTs have been set up in order to help people with depression (in a clinical setting). The MBCT approach combines mindfulness with elements of cognitive behavioural therapy and is, therefore, (unlike MBSR) more focused on people and their own possible activity. It helps them find out about themselves (i.e., how to work effectively with their minds). ${ }^{47}$ In other words, it puts emphasis on thinking and priorities in life, free of harmful stress. ${ }^{48}$

The general form, whether the MBSR or the MBCT course, consists of eight two-and-a-half-hour sessions over eight weeks (i.e., one week each), with an additional day of mindfulness after the last 6 weeks of the course. It also includes a structured homework plan that is crucial for course participants. It typically includes 45 minutes of formal mindfulness practice (body scan, sitting or walking meditation, yoga), including some informal practices such as observing and recording experiences/feelings throughout the program. Participants are asked to complete general questionnaires prior to entering the course, as well as to complete a pre-entry interview with a course instructor. ${ }^{49}$

The social worker, therefore, can use the comprehensive and structured training in mindfulness, through which this skill can be developed, cultivated and maintained under the professional supervision of the lecturer. Otherwise, he or she can obtain it himself or herself, through some book sources ('Mindfulness manuals' for self-teaching).

\section{Pitfalls and Potential Risks of Mindfulness}

The undisputed benefits of practising mindfulness are constantly proven through ongoing research. Some of them have been introduced here. There are countless proven positive effects of mindfulness practice. On the other hand, though, only a fraction of attention is devoted to the potential risks. There is not much knowledge available about these nowadays. ${ }^{50}$

In 2009, the science team led by Kathleen Lustyk pointed out the possible risks of practising different types of meditation (including mindfulness meditation). In their article, the team summed up studies that showed the adverse side effects among practitioners. These include, for example,

45 Cf. Shamash ALIDINA - Juliet ADAMS, Mindfulness at Work Essentials for Dummies, USA: John Wiley \& Sons, 2014.

46 Cf. Malcolm PAYNE, Modern Social Work..., p. 167.

47 Cf. Shamash ALIDINA - Juliet ADAMS, Mindfulness at Work Essentials for Dummies, USA: John Wiley \& Sons, 2014.

48 Cf. PAYNE, Modern Social Work..., p. 167.

49 Cf. Terry HYLAND, Mindfulness and Learning: Celebrating the Affective Dimension of Education, UK: Springer, 2011, p. 56.

50 Cf. ( ) Oxford Mindfulness Centre, Is Mindfulness Safe? (on-line), available at: http://oxfordmindfulness.org/news/is-mindfulness-safe, cited 3rd July 2017. 
depersonalisation (feeling of disconnection including mental processes or body), psychosis (loss of contact with reality) with delusions, hallucinations and disorganised communication, anxiety, increased risk of seizures, loss of appetite or insomnia. However, the research team itself mentions that the practices of screenings, safety research guides, or training standards for researchers have not yet been developed. ${ }^{51}$ Therefore, the outputs may be somewhat distorted. In addition, it is necessary to take into account the health status of the participants. Health condition plays a major role when dealing with unwanted mental and physical conditions. The authors of the research particularly mentioned people with PTSD (Posttraumatic Stress Disorder). Increased caution should be given when working with these individuals.

Another interesting insight was presented by Dr David Treleaven, the expert on spirituality and health. He described the fact that constant attention to the body (related to mindfulness) can lead to so-called 'contemplative dissociation'. It is a certain absence of interconnection related to thoughts, emotions and physical feelings. According to him, it occurs when the individual touches past physical or mental trauma (which has not yet been adequately processed) through the present moment (respectively through concentration on mental or physical conditions). It can lead him or her into pain that might last for a long time and it is hard to escape from. ${ }^{52}$

The abovementioned, therefore, suggests that it is necessary to devote more attention to the pitfalls, respectively to the risks associated with the practice of mindfulness. Due to the lack of relevant scientific knowledge, the risks cannot yet be highlighted. However, some of them were mentioned in this chapter.

\section{Conclusion}

Mindfulness has been (increasingly) the subject of various research. It has been usually used in psychology or medicine, but has recently become a priority in social work literature as well. In this area, mindfulness is a relatively new phenomenon that deserves deeper attention and further exploration. In the text, mindfulness was introduced as a potential and effective tool for the development of the social worker's personality. This was done through the interpretations of individual authors who have dealt with mindfulness. The term mindfulness is referred to as a 'gym of mind' or 'mental fitness' and is a certain adventurous way leading to self-knowledge and self-development, i.e., to the determiners leading to the developed and healthy personality of a social worker. ${ }^{53}$ Furthermore, the effectiveness of mindfulness has been demonstrated in existing social work related research that shows that mindfulness training evidently brings benefits into the personal and professional life of an individual. One cannot forget the fact that social workers have to deal with high demands and the profession of social work itself is associated with a high level of burden. ${ }^{54}$ These include, for example, the support of clients in diverse life situations and circumstances. Such demands can contribute to high levels of stress as well as to burnout syndrome. ${ }^{55} \mathrm{To}$ sum up, there is a constant increase in the professional requirements (by the company, the state,

51 Cf. Kathleen B. LUSTYK - Neharika CHAWLA - Roger S. NOLAN - Alan MARLATT, Mindfulness Meditation Research: Issues of Participant Screening, Safety Procedures, and Researcher Training, Advances 1/2009, pp. 20-30.

52 Cf. David TRELEAVEN, Meditation, Trauma, and Contemplative Dissociation, Somatics: Magazine-Journal of the Mind/Body Arts and Sciences 2/2010, pp. 20-22.

53 Cf. Vidyamala BURCH - Danny PENMAN, Meditace pro zdraví: Praktický průvodce pro zvládání bolesti, nemocí a stresu pomocí všímavosti, Praha: Grada, 2016, p. 198.

54 Cf. GÉRINGOVÁ, Pomáhající profese... p. 36; JANKOVSKÝ, Etika...,pp. 157-165; MATOUŠEK, Metody ..., pp. 51-60; Zdeněk MLČÁK, Potenciální zdroje stresu v sociální práci a jejich zvládání, Sociální práce / Sociálna práca 3/2005, pp. 124-137.

55 Cf. McGARRIGLE - WALSH, Mindfulness..., pp. 212-233. 
the clients) and, on the other hand, the permanent reduction of funds, the insufficient financial evaluation of social workers, the low prestige of the profession, the shortcomings in legislation, respectively its instability (mentioned, for example, by Paulík and Stejskalová). ${ }^{56}$

Mindfulness can be a creative and usable tool for social workers. It can significantly reduce the level of stress and balance the demands that one faces in life more effectively. Social workers can use mindfulness, for example, to prevent burnout syndrome and raise their awareness. ${ }^{57}$ The training of mindfulness can bring many benefits not only to the personality of a social worker but also into his or her practice. ${ }^{58}$ These include, for example: an increase in work performance, respectively work efficiency, improved communication and problem solving, increased concentration, increased ability to manage conflicts, achieving balance and resilience at the workplace and in the home environment, improving comprehensibility and empowering creative thinking, supporting mental and physical wellbeing, reducing stress levels, preventing burnout syndrome and emotional exhaustion, reduction of automatic responses (respectively the ability to make decisions more consciously), reducing chronic pain, improving energy levels, increasing control over long-term anxiety disorders, improving professional practice and working relationships ${ }^{59}$ However, it is necessary to realise that the practice of mindfulness is related to a certain discipline - that is, the observance of specific and necessary principles by social workers. These are a key prerequisite for using the positive consequences of the mindfulness practice and are outlined in the article.

The opportunities for social workers (to develop, improve, and maintain awareness, and take advantage of their potential for personality development) have been also mentioned. It can be achieved through special courses (MBSR or MBCT mindfulness training), which are similar to a large extent. In addition, social workers can go through training themselves, with the support of book sources (i.e., self-teaching).

Finally, the 'pitfalls of mindfulness' were discussed, i.e., some of the risks that can be associated with practice. Due to the lack of scientific knowledge, however, close attention has to be paid to them. Also, the resources addressing the potential pitfalls of mindfulness have to become wider. Mindfulness, as a potential tool for the development of social worker's personality, has certainly great potential and it can be assumed that more and more research will be devoted to its beneficial consequences in personality development.

56 Cf. PAULÍK, K otázce..., p. 293; Jana STEJSKALOVÁ, Krize sociální práce aneb máme to ještě ve svých rukou?, Sociální práce / Sociálna práca 3/2014, p. 11.

57 Cf. LEONARD, Breathe In..., p. 2.

58 Cf. Louise GRANT - Gail KINMAN, Developing Resilience for Social Work Practice, UK: Palgrave, 2014.

59 Cf. @ SSSC News, Bringing Mindfulness... 


\title{
Mindfulness as a Potential Tool for Developing the Personality of the Social Worker
}

\begin{abstract}
This article represents mindfulness as a potential tool for the development of the social worker's personality through which mental health and, consequently, physical state can be effectively maintained. At first, mindfulness is approached through the interpretations of various authors. Its perspective is further supported by the results of various scientific researches. The current state of mindfulness raising in social work (including traditional, official courses MBSR, $M B C T$ ) is introduced. Through these courses mindfulness can be developed, improved and maintained. Finally, space is also given to the 'pitfalls of mindfulness, i.e., to the risks that can be associated with its practice.
\end{abstract}

Key Words: social work, social worker, mindfulness, personality, development

\section{Author contact \\ Michal Kaczor MA}

University of South Bohemia in České Budějovice

Faculty of Theology, Department of Ethics, Psychology and Charity Work

Kněžská 8, 37001 České Budějovice

Email: info@michalkaczor.cz 